\title{
Assessing the Racial Differences in $Q$ Angle Measurements in Relevance to Articular Cartilage of the Femoral Condyle: A Retrospective Ultrasound Study
}

\author{
Evaluación de las Diferencias Raciales en las Mediciones del Ángulo Q en Relación \\ con el Cartílago Articular del Cóndilo Femoral: Un Estudio Ecográfico Retrospectivo
}

\author{
Ramada R Khasawneh ${ }^{1}$; Fatimah A. Almahasneh ${ }^{1}$ \& Ejlal Abu-El Rub ${ }^{1}$
}

KHASAWNEH, R. R.; ALMAHASNEH, F. A. \& ABU-EL RUB, E. Assessing the racial differences in Q angle measurements in relevance to articular cartilage of the femoral condyle: A retrospective ultrasound study. Int. J. Morphol., 39(6):1776-1781, 2021.

SUMMARY: The Q-angle is defined as the acute angle formed by the vectors for combined pull of the quadriceps femoris muscle and the patellar tendon. This study aimed to investigate the variations in Q angle with respect to race. Moreover, this study performed ultrasound to evaluate of the thickness of articular cartilage covering the medial and lateral femoral condyle in volunteers with an increased Q angle. The study included 487 Jordanian and 402 Malaysians with age range 18-23 years. Moreover, the study included 30 participants aged between 18 and 22 years, with a total of 15 volunteers with $\mathrm{Q}>14^{\circ}$ and 15 patients with $\mathrm{Q} \leq 14^{\circ}$. Both $\mathrm{Q}$ angle and condylar distance were measured by well-trained medical practitioners according to a well-established protocol. The thickness of articular cartilage covering the medial and lateral femoral condyle of the femoral bone was measured using ultrasound. Regardless of race, Q angle was greater in females. Furthermore, Q angle was significantly greater in Arab volunteers compared to Malay volunteers. Q angle significantly increase with increasing condylar distance in both races. Finally, the statistical analysis showed a significantly reduced thickness of articular cartilage on both medial and lateral femoral condyle $(\mathrm{P}=0.05)$ in the $\mathrm{Q}>14^{\circ}$ group. Multiple factors including race and condylar distance and even the articular cartilage of femoral condyle should be considered during the examination and management of knee fractures and condylar diseases.

KEY WORDS: Q angle; Knee; Race; Articular cartilage; Ultrasound.

\section{INTRODUCTION}

The $\mathrm{Q}$ angle (quadriceps angle) was first described in 1964 by Brattstroem (1964), who defined it as the angle formed between the quadriceps muscle and the patella tendon. The $\mathrm{Q}$ angle is formed by the intersection of the line going from the anterosuperior iliac spine (ASIS) to the center of the patella and the line between the anterior tuberosity of the tibia and the center of the patella (Almeida et al., 2016).

The $\mathrm{Q}$ angle describes the effect of quadriceps mechanics on the movement of the knee (Loudon, 2016). It is also used to assess the function of the knee and its health in patients with anterior knee pain (Chhabra et al., 2016; Loudon). Q angle is of particular importance for athletes and physically active individuals, since it describes the alignment of the pelvis, leg and foot (Nguyen et al., 2009; Daneshmandi et al., 2011; Almeida et al.).
Different values for $\mathrm{Q}$ angle were reported in literature. Generally, the normal range lies between 12 to 20 degrees (Jaiyesimi \& Jegede, 2010), although some studies consider values between $8^{\circ}$ and $10^{\circ}$ to be normal (Khasawneh et al., 2019). Males show lower values than females (Jaiyesimi \& Jegede; Tella et al., 2010). Angles larger than $20^{\circ}$ are considered excessive (Davies, 1978).

An excessive $\mathrm{Q}$ angle impedes the smooth movement of the patella in the femoral groove, which adds biomechanical stress on the knee during repetitive activities (Chhabra et al.; Loudon). This may lead over time to muscle imbalance and eventual wearing and loss of knee cartilage (Tsakoniti et al., 2011). In addition, excessive Q angle may increase foot pronation, which produces excessive internal rotation of the tibia. The latter can change the quadriceps

${ }^{1}$ Department of Basic Medical Sciences, Faculty of Medicine, Yarmouk University, Irbid, Jordan. 
mechanics and lateral tracking of the patella (Tiberio, 1987), eventually resulting in patella femoral arthralgia and degenerative joint disease. Indeed, the effects of abnormal Q angle can often be reduced by controlling the pronation of the foot (Piva et al., 2009).

Only a few studies have addressed the differences in $\mathrm{Q}$ angle among various ethnicities, such as the study by Ebeye et al. (2014), which described differences in the $Q$ angle values across the various ethnic groups in Nigeria. Another study found that Q angle in Nigerian women is larger than that of Caucasian women (Omololu et al., 2009). The values of the $\mathrm{Q}$ angle in Arab population were found to be relatively higher than those reported in other countries and ethnicities (Khasawneh et al.).

Our study aimed to detect potential differences in the $\mathrm{Q}$ angle between the Arab and Malay ethnicities. In addition, we measured the thickness of the surface cartilage of the femoral condyle and assessed its correlation to the $\mathrm{Q}$ angle.

\section{MATERIAL AND METHOD}

Study sample. A total of 487 ( 236 male/ 251 female) Jordanian representing the Arab race and 402 (212 male/190 female) Malaysians representing the Malay race were included in the study. Malaysian volunteers from Indian and Chinese racial backgrounds were excluded from the study. All participants were students at Yarmouk University and Jordan University of Science and Technology (JUST) in Jordan. All participants were right-leg dominant with age range between 18 and 23 years. To determine the leg dominancy, the volunteers were asked to kick a ball, the leg dominancy was determine based on their performance. Participants with musculoskeletal pathology that could influence the Q-angle were excluded from the study. The Q angle measurements have been performed bilaterally for each volunteer.

Measurement procedure. Ethical clearance for the study was obtained from the Institutional Research Board at Jordan University of Science and Technology (IRB \# 7/134/2020). The procedure was explained to the subjects who then signed an informed consent form before embarking on the measurements. The nationalities, age, sex, weight, height, and dominant side were recorded on a specific investigation paper sheet. The determination of the leg dominance was based on their individual preference when being asked to kick a ball. The $Q$ angle was measured with a full circle universal manual goniometer made of clear plastic with the subject standing in the erect weight-bearing position, according to the method described by Khasawneh et al. This method had been reported to produce accurate measurements with an error margin of \pm $1^{\circ}$. In brief, the anterior superior iliac spine (ASIS), the midpoint of the patella, and the tibial tuberosity were determined. The hinge of the goniometer was located at the midpoint of the patella, the goniometer arms were adjusted to become positioned to the line joining the ASIS and the line joining the tibia tuberosity, and the small angle on the goniometer was then read as the Q angle. Both sides were measured for each individual. Each side was measured 3 times, and the mean value of the angle was calculated.

A manual metal caliper, scaled from $0 \mathrm{~cm}$ to $20 \mathrm{~cm}$ and with a marginal error of $\pm 1 \mathrm{~mm}$, was used to measure the condylar distance of the femur for both sides of each volunteer. The subject first stood in the anatomical position with the feet facing forward, and the leg was flexed to $90^{\circ}$ with the result that the femoral condyles became prominent and easily palpable at that position. After the fixed arm of the caliper was placed on the lateral condyle, and the movable arm was then adjusted to the medial condyle; the condylar distance measurement for each side.

A total of 60 subjects (30 Jordanian/30 Malaysians) from the first group volunteered for an ultrasound study. The volunteers were divided into two groups; the first one included 30 individuals with $\mathrm{Q}$ angles $\leq 14^{\circ}$ and the second group 30 individuals with $\mathrm{Q}$ angle $>14^{\circ}$. All volunteers were informed about the purpose of the research and gave voluntary informed consent to participate in the study. Ultrasound (US) examination of the knee joint articular cartilage was conducted using a HONDA HS-2200 with 6.0/8.5/11.00 MHz highresolution linear transducer. The knee was examined with the patient supine; the knee was positioned with full flexion. The transducer was applied transversely just above the patella, perpendicular to the surface of the femoral condyles. The obtained images were used to measure the thickness of homogeneous low echoic or anechoic cartilaginous structure using ultrasound software (Fig. 1). The measurement of the articular cartilage covering the lateral and medial femoral condyle was repeated 3 times and the mean value was calculated. Both limbs were evaluated by the same operator.

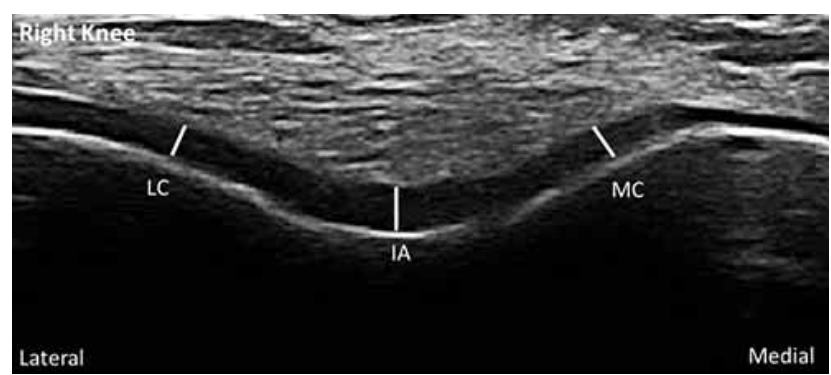

Fig. 1. Femoral cartilage thickness measurements via ultrasound. LC. Lateral condyle; IA. Intercondylar area; MC. Medial condyle. 
After collecting the requested information and measurements, the data were transferred into a computer to perform the required statistical analysis.

Statistical analysis. Levene test was applied to determine the homogeneity of variance, the data were evaluated by one-way analysis of variance (ANOVA) or independent samples t-test at 0.05 and 0.01 levels of significance. When needed the Scheffe post hoc analysis test was performed to examine statistical differences between the groups when necessary. For multiple comparison of cartilage thickness for both condyles the Bonferroni test was used. The data were presented as mean \pm standard error of the mean (SEM).

\section{RESULTS}

Variation in $\mathbf{Q}$ angle and condylar distance with race. Both Arab and Malay races demonstrated variation in Q angle with sex similar to previous reports (Table I). When the two racial groups were compared, the $\mathrm{Q}$ angle was significantly $(\mathrm{P}<0.01)$ greater on both sides in Arab males compared to Malay males (Table I; Fig. 2). Similarly, Arab females had significantly $(\mathrm{P}<0.01)$ larger $\mathrm{Q}$ angle in both sides than Malay females (Fig. 2).

It was already being published that a significant increase in $\mathrm{Q}$ angle was observed as the condylar distance increased in Arab populations, so we assess the relationship between the condylar distance and the $\mathrm{Q}$ angle. The Malay volunteers were divided into 3 groups according to length of their condylar distance. Each group included a condylar distance with $10 \mathrm{~mm}$ interval. Similar to Arabs, a significant $(\mathrm{P}<0.05)$ increase in $\mathrm{Q}$ angle with increased condylar distance was observed in both male and female Malay participants (Tables II and III). On the other hand, the Malay participants showed a smaller condylar distance comparing to Arab populations.

Table I. Measurements of the $\mathrm{Q}$ angle with respect to sex and side in Arab and Malay participants

\begin{tabular}{lllll}
\hline Sex & \multicolumn{2}{c}{ Arab Race } & \multicolumn{2}{c}{ Malay Race } \\
\cline { 2 - 5 } & Right Q angle & Left Q angle & Right Q angle & Left Q angle \\
\hline Male & $14.2 \pm 0.42$ & $13.9 \pm 0.51$ & $10.65 \pm 0.32$ & $10.3 \pm 0.55$ \\
Female & $17.4 \pm 0.53 * *$ & $17 \pm 0.93 * *$ & $13.7 \pm 0.49 *$ & $13.36 \pm 0.62 * *$ \\
\hline$* P<0.05 ; * * \mathrm{P}<0.01$, significantly greater than the corresponding side in males (t-test).
\end{tabular}

Table II. Variation of the Q angle with condylar distance of the femur in Malay males participants.

\begin{tabular}{lll}
\hline Condylar distance $(\mathrm{cm})$ & Right Q angle & Left Q angle \\
\hline $7-7.9$ & $10.1 \pm 0.24$ & $10 \pm 0.36$ \\
$8-8.9$ & $10.3 \pm 0.42$ & $10.1 \pm 0.25$ \\
$9-9.9$ & $11.5 \pm 0.34^{*}$ & $11 \pm 0.37^{*}$ \\
\hline
\end{tabular}

${ }^{*} P<0.05$; a significant increase in $\mathrm{Q}$ angle as the condylar distance increases in both sides (ANOVA, LSD post hoc).
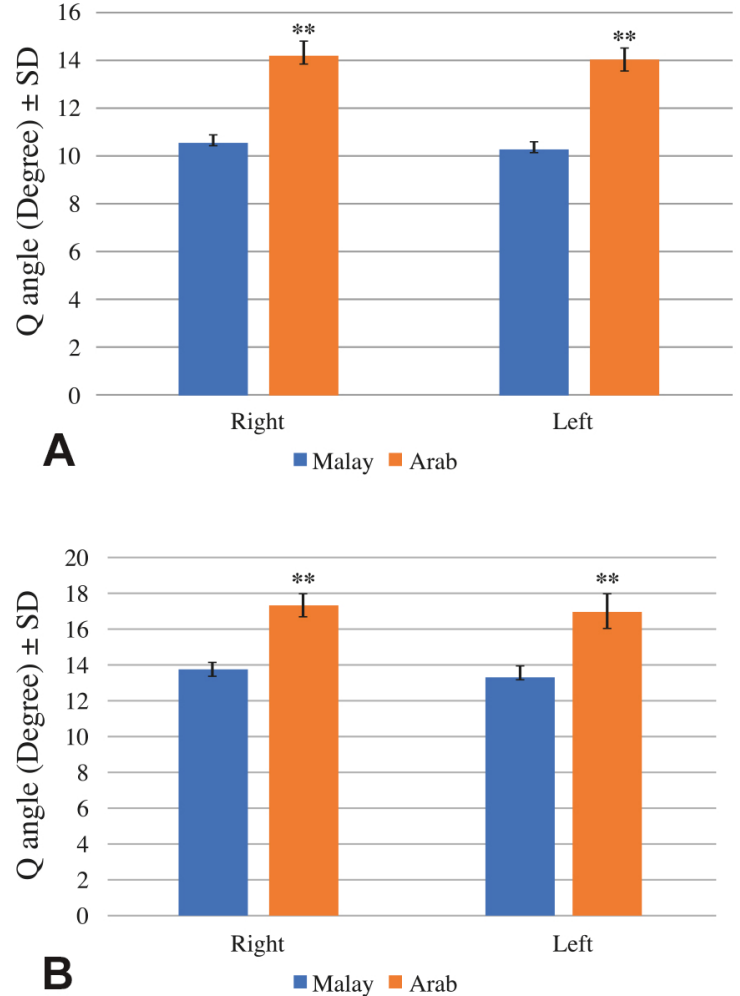

Fig. 2. Variation of the Q angle between Arab and Malay racial groups. A. Males; B. Females. Each column represents the mean $\mathrm{Q}$ angle \pm standard error of the mean $(\mathrm{SEM}) ; * \mathrm{P}<$ 0.01 compared to the same side and sex of the other race ( $t$ test).

Thickness of the surface cartilage of the femoral condyle. The thickness of surface cartilage the medial and the lateral femoral condyles in both groups are shown in Table IV. The mean cartilage thickness \pm SDis shown in Table V.

The statistical analysis showed a significant reduction in the thickness of both medial $(\mathrm{P}=0.05)$ and lateral $(\mathrm{P}=0.00)$ femoral condyle articular cartilage in the $\mathrm{Q}>14^{\circ}$ group (Fig. 3). On the other hand, no significant difference was found between the right and left side of the same $\mathrm{Q}$ angle group $\left(\mathrm{Q}>14^{\circ}\right.$ or $\mathrm{Q} \leq 14^{\circ}$ groups $)$ (Table IV).

Table III. Variation of the Q angle with condylar distance of the femur in Malay females participants.

\begin{tabular}{lcc}
\hline $\begin{array}{l}\text { Condylar } \\
\text { distance }(\mathrm{cm})\end{array}$ & Right Q angle & Left $\mathrm{Q}$ angle \\
\hline $6.5-7.4$ & $13.5 \pm 0.24$ & $13.1 \pm 0.36$ \\
$7.5-8.4$ & $13.8 \pm 0.42$ & $13.3 \pm 0.25$ \\
$8.5-9.5$ & $14.3 \pm 0.34 *$ & $13.9 \pm 0.37 *$ \\
\hline $\begin{array}{l}* \\
\text { distance increases in both sides (ANOVA, LSD post hoc). }\end{array}$
\end{tabular}


KHASAWNEH, R. R.; ALMAHASNEH, F. A. \& ABU-EL RUB, E. Assessing the racial differences in Q angle measurements in relevance to articular cartilage of the femoral condyle: A retrospective ultrasound study. Int. J. Morphol., 39(6):1776-1781, 2021

Table IV. The thickness of the articular cartilage covering the femoral condyle in volunteers.

\begin{tabular}{|c|c|c|c|c|c|c|c|c|}
\hline \multicolumn{9}{|c|}{ Articular cartilage thickness (mm) } \\
\hline & \multicolumn{4}{|c|}{ Q angle $\leq 14^{\circ}$} & \multicolumn{4}{|c|}{$\mathrm{Q}$ angle $>14^{\circ}$} \\
\hline \multirow[b]{2}{*}{ Patient number } & \multicolumn{2}{|c|}{ Lateral femoral } & \multicolumn{2}{|c|}{ Medial femoral } & \multicolumn{2}{|c|}{ Lateral femoral } & \multicolumn{2}{|c|}{ Medial femoral } \\
\hline & Left side & $\begin{array}{l}\text { Right } \\
\text { side }\end{array}$ & Left side & Right side & Left side & Right side & Left side & $\begin{array}{l}\text { Right } \\
\text { side }\end{array}$ \\
\hline 1 & 2.05 & 1.99 & 1.95 & 2.1 & 1.39 & 1.44 & 1.41 & 1.43 \\
\hline 2 & 2 & 2.05 & 1.97 & 2.04 & 1.44 & 1.45 & 1.47 & 1.5 \\
\hline 3 & 2.1 & 2.1 & 1.99 & 2.15 & 1.47 & 1.52 & 1.5 & 1.53 \\
\hline 4 & 1.98 & 2.02 & 2 & 2.08 & 1.5 & 1.61 & 1.55 & 1.64 \\
\hline 5 & 2.4 & 2.42 & 2.37 & 2.41 & 1.42 & 1.51 & 1.48 & 1.5 \\
\hline 6 & 1.7 & 1.8 & 1.78 & 1.87 & 1.34 & 1.47 & 1.38 & 1.42 \\
\hline 7 & 2.2 & 2.31 & 2.25 & 2.4 & 1.44 & 1.5 & 1.49 & 1.51 \\
\hline 8 & 1.8 & 1.89 & 1.82 & 1.95 & 1.54 & 1.58 & 1.55 & 1.6 \\
\hline 9 & 1.97 & 2.05 & 2 & 2.1 & 1.52 & 1.62 & 1.56 & 1.6 \\
\hline 10 & 2.5 & 2.56 & 2.58 & 2.6 & 1.47 & 1.55 & 1.51 & 1.54 \\
\hline 11 & 2.25 & 2.5 & 2.31 & 2.45 & 1.58 & 1.63 & 1.6 & 1.65 \\
\hline 12 & 2.15 & 2.24 & 2.19 & 2.28 & 1.37 & 1.43 & 1.37 & 1.41 \\
\hline 13 & 1.68 & 1.78 & 1.71 & 1.77 & 1.37 & 1.48 & 1.41 & 1.46 \\
\hline 14 & 2.52 & 2.5 & 2.52 & 2.54 & 1.43 & 1.59 & 1.47 & 1.52 \\
\hline 15 & 2.21 & 2.36 & 2.28 & 2.31 & 1.48 & 1.6 & 1.52 & 1.57 \\
\hline 16 & 1.89 & 2.07 & 1.92 & 2.06 & 1.44 & 1.61 & 1.54 & 1.58 \\
\hline 17 & 2.45 & 2.5 & 2.49 & 2.53 & 1.6 & 1.66 & 1.63 & 1.68 \\
\hline 18 & 2.45 & 2.58 & 2.46 & 2.6 & 1.35 & 1.44 & 1.39 & 1.4 \\
\hline 19 & 1.77 & 1.87 & 1.82 & 1.88 & 1.39 & 1.52 & 1.45 & 1.52 \\
\hline 20 & 2.53 & 2.6 & 2.61 & 2.64 & 1.52 & 1.59 & 1.55 & 1.56 \\
\hline 21 & 2.03 & 2.34 & 2.12 & 2.27 & 1.41 & 1.53 & 1.48 & 1.52 \\
\hline 22 & 1.99 & 2.21 & 2.04 & 2.15 & 1.45 & 1.54 & 1.46 & 1.5 \\
\hline 23 & 2.24 & 2.34 & 2.3 & 2.34 & 1.48 & 1.59 & 1.51 & 1.55 \\
\hline 24 & 2.07 & 2.3 & 2.14 & 2.26 & 1.43 & 1.5 & 1.44 & 1.56 \\
\hline 25 & 1.79 & 1.85 & 1.81 & 1.84 & 2 & 2.21 & 2.05 & 2.16 \\
\hline 26 & 2.53 & 2.61 & 2.58 & 2.6 & 1.43 & 1.49 & 1.44 & 1.45 \\
\hline 27 & 2.47 & 2.58 & 2.5 & 2.54 & 1.44 & 1.57 & 1.48 & 1.53 \\
\hline 28 & 2.33 & 2.43 & 2.37 & 2.43 & 1.45 & 1.6 & 1.54 & 1.59 \\
\hline 29 & 1.86 & 2 & 1.92 & 2.01 & 1.61 & 1.72 & 1.67 & 1.71 \\
\hline 30 & 2.09 & 2.3 & 2.1 & 2.21 & 1.36 & 1.43 & 1.4 & 1.43 \\
\hline 31 & 2.31 & 2.56 & 2.43 & 2.55 & 1.46 & 1.51 & 1.46 & 1.49 \\
\hline Average & $2.139^{* *}$ & $2.248^{*}$ & $2.171^{*}$ & $2.256^{*}$ & 1.47 & 1.564 & 1.5 & 1.55 \\
\hline
\end{tabular}

$* \mathrm{P}<0.05, * * \mathrm{P}<0.00$; significant increase in the thickness of both right and left femoral condyle articular cartilage in the $\mathrm{Q} \leq 14^{\circ}$ group. No significant difference found between the right and left side in the same $\mathrm{Q}$ angle group. (ANOVA, LSD post hoc).

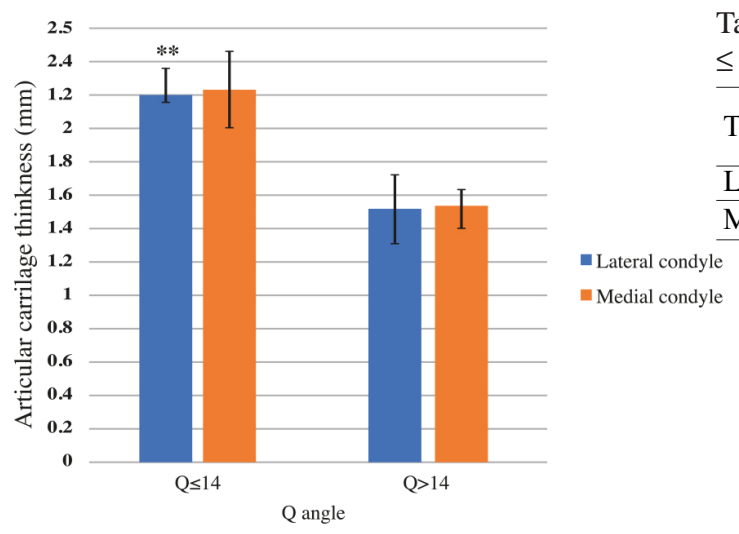

Fig. 3. A relationship between the thickness of condyyle articular cartilage and the Q-angle. Each column represents the mean $\mathrm{Q}$ angle \pm standar error of the mean (SEM). The figure shows a significant increase in thickness of lateral femoral condyle articular cartilage $(\mathrm{P}$ $=0.00)$ in the $\mathrm{Q} \leq 14^{\circ}$ group. $+\mathrm{P}<0.05 ; * * \mathrm{P}<0.01$ (t-test).
Table V. The thickness of the articular cartilage covering the condyles in the Q $\leq 14^{\circ}$ and $\mathrm{Q}>14^{\circ}$ groups.

\begin{tabular}{lcc}
\hline \multirow{2}{*}{ The condylar distance } & \multicolumn{2}{c}{ Articular cartilage thickness $[\mathrm{mm}]($ mean \pm SD) } \\
\cline { 2 - 3 } & $\mathrm{Q}$ angle $\leq 14$ & $\mathrm{Q}$ angle $>14$ \\
\hline Lateral femoral condyle & $2.191 \pm 0.15$ & $1.515 \pm 0.19$ \\
\hline Medial femoral condyle & $2.2135 \pm 0.23$ & $1.525 \pm 0.11$
\end{tabular}

\section{DISCUSSION}

The quadriceps angle ( $\mathrm{Q}$ angle) is considered an important parameter for the clinical evaluation of quadriceps forces and the factors affecting the patella femoral joint. It is used in the diagnosis of several knee joint disorders, and in the assessment of sports performances. Excessive values for $\mathrm{Q}$ angle may result from abnormal knee alignment, which 
KHASAWNEH, R. R.; ALMAHASNEH, F. A. \& ABU-EL RUB, E. Assessing the racial differences in Q angle measurements in relevance to articular cartilage of the femoral condyle: A retrospective ultrasound study. Int. J. Morphol., 39(6):1776-1781, 2021

increases the lateral force on the patella. Such increase may cause an excessive compression of the lateral patella on the lateral lip of the femoral sulcus, leading to the potential subluxation or dislocation of the patella. Abnormal $Q$ angle was also associated with changes in neuromuscular response and quadriceps reflex response time, making it a risk factor for the anterior cruciate ligament injury (Griffin et al., 2000). Values of Q angles are affected by sex, and females show significantly higher values than males (Khasawneh et al.). Our study found that the values of $\mathrm{Q}$ angle in males were lower than those in females. These results agree with previously reported findings (Tella et al.; Khasawneh et al.). A few theories have been suggested to explain sex-related differences in the values of $\mathrm{Q}$ angle. Females have wider pelvis than males, which makes the distance between the pelvis and the patella longer than that from the patella to the tibial tuberosity. This induces an alternation in the position of the anterior superior iliac spine, which impacts $\mathrm{Q}$ angle values (Grelsamer et al., 2005). Previous studies had revealed an inverse relation between the value of $\mathrm{Q}$ angle and the individual's height. Since men tend to be taller than women, their Q angle values are smaller than females' values (Jaiyesimi \& Jegede). Higher Q angle values in females are associated with increased compression of articulating surfaces, and this may explain the higher risk of patella femoral pain in this group (Khasawneh et al.). Some authors also point to an increased risk of patellar chondromalacia as well as patellar dislocation and subluxation (Barberie et al., 1998) if the Q angle $>15-20^{\circ}$.

The potential role of ethnicity in Q angle values was not extensively studied. The values of $Q$ angle measured in the Arab population were higher than those reported in other ethnicities (Khasawneh et al.). Differences were also found among various ethnic groups in Nigeria (Ebeye et al.) and between Nigerian women and their Caucasian counterparts (Omololu et al.). Our study directly compared the values of Q angles in two ethnic groups, Arabic and Malay. The $\mathrm{Q}$ angle was significantly $(\mathrm{P}<0.01)$ greater on both sides in Arab males and females compared to their Malay counterparts.

It has long been speculated that $\mathrm{Q}$ angle may differ in relation to race. Moreover, differences between studied populations have been suggested to underlie conflicting data about Q angle in the literature (Omololu et al.; Raveendranath et al., 2011; Khasawneh et al.). Moreover, Hovinga \& Lerner (2009) reported some observation about the role of ethnicity on the variation of $\mathrm{Q}$ angle. It could be argued that this variation might be due to differences in physical parameters such as height and weight between the Arab and Malay participants. However, our statistical analysis revealed no significant difference in height or weight in either male or female participants of the two races. In our previous work, we found that Q angle is directly correlated with the condylar distance of the femur in the study group regardless of which side is measured (Khasawneh et al.). As a result, we assessed the relationship between the condylar distance and the Q angle in Malay race. We found that the $\mathrm{Q}$ angle increases as the condylar distance increases similar to Arab race. On the other hand, the Malay race showed a smaller condylar distance comparing to Arab race. These findings provide a plausible explanation for why the Q angle is significantly larger in Arab race comparing to Malay race.

In this study we used ultrasound regarding the thickness of femoral condyle articular cartilage, and according to our knowledge this is the first study to investigate the thickness of femoral condyle cartilage and its relation to the $\mathrm{Q}$ angle.

Ultrasonography is a widely used imaging technique for the diagnosis and assessment of any musculoskeletal system related pathology. Ultrasound is considered superior to another imaging technique due to its availability, short scan time and low costs. Moreover, it allows for a better visualization of detailed knee structures such as muscles, ligaments, periarticular tissues and fluid cisterns (Grobbelaar \& Bouffard, 2000), and detects any abnormality that may present in the knee (Hsieh et al., 1998).

The results showed a significant reduction in the thickness of right femoral condyle cartilage $(P=0.05)$ was observed in the $\mathrm{Q}>14^{\circ}$ group. Moreover, the data showed a significantly reduced thickness of the left femoral condyle articular cartilage $(\mathrm{P}=0.00)$ in the same group. These findings agree with previous reports of a negative correlation between high Q values and cartilage thickness of the medial femoral condyle in female patients with knee osteoarthritis (Ekim et $a l ., 2017)$. In another study, the thickness of the articular cartilage on the lateral femoral condyle was found to be reduced in women with the $\mathrm{Q}$ angle $>15^{\circ}$ (Kusiak \& Kawczyn'ski, 2018). This reduction in cartilage thickness may be an adaptive response to increased compression applied by the patellar cartilage on this condyle, as found by Mizuno et al. (2001).

Our findings indicate a significant reduction in the thickness of femoral articular cartilage with increase Q-angle value. This can happen as a result of the increased compression imposed by the patellar cartilage on the condyle.

This study supports the role of sex in influencing the value of Q angle independent of the age, race and dominant side factors. It also provides a new evidence about the variation of $\mathrm{Q}$ angle between different races. Finally, it determines the presents of an inverse relationship between the $\mathrm{Q}$ angle and the thickness of the femoral articular cartilage 
which has never been demonstrated before. These data are clinically important for the examination and the management of knee fractures and may help in predicting the ethnic identity in forensic medicine.

KHASAWNEH, R. R.; ALMAHASNEH, F. A. \& ABU-EL RUB, E. Evaluación de las diferencias raciales en las mediciones del ángulo Q en relación con el cartílago articular del cóndilo femoral: un estudio ecográfico retrospectivo. Int. J. Morphol., 39(6):1776-1781, 2021.

RESUMEN: El ángulo Q se define como el ángulo agudo formado por los vectores de tracción combinada del músculo cuádriceps femoral y el tendón patelar. Este estudio tuvo como objetivo investigar las variaciones en el ángulo Q con respecto a la raza. Además, se realizó una ecografía para evaluar el grosor del cartílago articular que cubre los cóndilos femorales medial y lateral en voluntarios con un ángulo Q aumentado. El estudio incluyó a 487 jordanos y 402 malayos con un rango de edad de 18 a 23 años. Además, el estudio incluyó a 30 participantes con edades comprendidas entre 18 y 22 años, 15 voluntarios con $\mathrm{Q}>14^{\circ}$ y 15 pacientes con $\mathrm{Q} \leq 14^{\circ}$. Tanto el ángulo $\mathrm{Q}$ como la distancia condilar fueron medidos por médicos bien entrenados de acuerdo con un protocolo establecido. El grosor del cartílago articular que cubre los cóndilos femorales medial y lateral del fémur se midió mediante ecografía. Independientemente del grupo racial, el ángulo Q fue mayor en las mujeres. Además, el ángulo Q fue significativamente mayor en los voluntarios árabes en comparación con los voluntarios malayos. El ángulo Q se aumenta significativamente al incrementarse la distancia condilar en ambas grupos raciales. Finalmente, el análisis estadístico mostró una reducción significativa del grosor del cartílago articular en los cóndilos femorales medial y lateral $(\mathrm{P}=0,05)$ en el grupo $\mathrm{Q}>14$. Durante la exploración y el tratamiento de las fracturas de rodilla y de las enfermedades condilares, se deben considerar múltiples factores, incluida la raza y la distancia condilar e incluso el cartílago articular del cóndilo femoral.

PALABRAS CLAVE: Ángulo Q; Rodilla; Carrera; Cartílago articular.

\section{REFERENCES}

Almeida, G. P. L.; Carvalho e Silva, A. P. M. C.; França, F. J. R.; Magalhães, M. O.; Burke, T. N. \& Marques, A. P. Q-angle in patellofemoral pain: relationship with dynamic knee valgus, hip abductor torque, pain and function. Rev. Bras. Ortop., 51(2):181-6, 2016.

Barberie, J. E.; Wong, A. D.; Cooperberg, P. L. \& Carson, B. W. Extended fieldof-view sonography in musculoskeletal disorders. AJR Am. J. Roentgenol., 171(3):751-7, 1998

Brattstroem, H. Shape of the intercondylar groove normally and in recurrent dislocation of patella: a clinical and x-ray anatomical investigation. Acta Orthop. Scand. Suppl., 68 Suppl. 68:1-148, 1964.

Chhabra, P. K.; Setiya, M. \& Godwin, R. "Quadriceps angle": An Important Indicator of Biomechanical Function of Lower Extremity and Its Relation with Anterior Knee Pain. Int. J. Sci. Stud., 4:173-6, 2016.

Daneshmandi, H.; Saki, F.; Shahheidari, S. \& Khoori, A. Lower extremity malalignment and its linear relation with Q angle in female athletes. 3rd World Conf. Educ. Sci., 15:3349-54, 2011

Davies, L. Examining the knee. Am. Phys. Ther. Assoc. Sports Med., 6:49-67, 1978.
Ebeye, O. M.; Okwoka, B. \& Abade, P. Influence of gender on quadriceps (Q) angle among adult Urhobos in Nigeria population. J. Exp. Clin. Anat., 13:50, 2014.

Ekim, A. A.; Hamarat, H. \& Musmul, A. Relationship between q-angle and articular cartilage in female patients with symptomatic knee osteoarthritis: ultrasonographic and radiologic evaluation. Arch. Rheumatol., 32(4):347-52, 2017.

Grelsamer, R. P.; Dubey, A. \& Weinstein, C. H. Men and women have similar Q angles: a clinical and trigonometric evaluation. J. Bone Joint Surg. Br., 87(11):1498-501, 2005.

Griffin, L. Y.; Agel, J.; Albohm, M. J.; Arendt, E. A.; Dick, R. W.; Garrett, W. E.; Garrick, J. G.; Hewett, T. E.; Huston, L.; Ireland, M. L.; et al. Noncontact anterior cruciate ligament injuries: risk factors and prevention strategies. $J$. Am. Acad. Orthop. Surg., 8(3):141-50, 2000.

Grobbelaar, N. \& Bouffard, J. A. Sonography of the knee, a pictorial review. Semin. Ultrasound CT MR, 21(3):231-74, 2000.

Hovinga, K. R. \& Lerner, A. L. Anatomic variations between Japanese and Caucasian populations in the healthy young adult knee joint. J. Orthop. Res., 27(9):1191-6, 2009.

Hsieh, Y. F.; Draganich, L. F.; Ho, S. H. \& Reider, B. The effects of removal and reconstruction of the anterior cruciate ligament on patellofemoral kinematics. Am. J. Sports Med., 26(2):201-9, 1998.

Jaiyesimi, A. \& Jegede, O. Influence of gender and leg dominance on q-angle among young adult Nigerians. Afr. J. Physiother. Rehabil. Sci., 1:18-23, 2010.

Khasawneh, R. R.; Allouh, M. Z. \& Abu-El-Rub, E. Measurement of the quadriceps (Q) angle with respect to various body parameters in young Arab population. PLoS One, 14(6):e0218387, 2019.

Kusiak, M. \& Kawczyn'ski, A. Ultrasonographic assessment of articular cartilage of the femoral condyle in patients with an increased Q-angle. J. Ultrason., 18(74):181-5, 2018.

Loudon, J. K. Biomechanics and pathomechanics of the patellofemoral joint. Int. J. Sports Phys. Ther., 11(6):820-30, 2016.

Mizuno, Y.; Kumagai, M.; Mattessich, S. M.; Elias, J. J.; Ramrattan, N.; Cosgarea, A. J. \& Chao, E. Y. Q-angle influences tibiofemoral and patellofemoral kinematics. J. Orthop. Res., 19(5):834-40, 2001.

Nguyen, A. D.; Boling, M. C.; Levine, B. \& Shultz, S. J. Relationships between lower extremity alignment and the quadriceps angle. Clin. J. Sport Med., 19(3):201-6, 2009.

Omololu, B. B.; Ogunlade, O. S. \& Gopaldasani, V. K. Normal Q-angle in an adult Nigerian population. Clin. Orthop., 467(8):2073-6, 2009.

Piva, S. R.; Fitzgerald, G. K.; Irrgang, J. J.; Fritz, J. M.; Wisniewski, S.; McGinty, G. T.; Childs, J. D.; Domenech, M. A.; Jones, S. \& Delitto, A. Associates of physical function and pain in patients with patellofemoral pain syndrome. Arch. Phys. Med. Rehabil., 90(2):285-95, 2009.

Raveendranath, R.; Nachiket, S.; Sujatha, N.; Priya, R. \& Rema, D. Bilateral variability of the quadriceps angle (q angle) in an adult Indian population. Iran. J. Basic Med. Sci., 14:465-71, 2011.

Tella, B. A.; Ulogo, U.; Odebiyi, D. O. \& Omololu, A. B. Gender variation of bilateral Q-angle in young adult Nigerians. Niger. Q. J. Hosp. Med., 20(3):114$6,2010$.

Tiberio, D. The effect of excessive subtalar joint pronation on patellofemoral mechanics: a theoretical model. J. Orthop. Sports Phys. Ther., 9(4):160-5, 1987.

Tsakoniti, A. E.; Mandalidis, D. G.; Athanasopoulos, S. I. \& Stoupis, C. A. Effect of Q-angle on patellar positioning and thickness of knee articular cartilages. Surg. Radiol. Anat., 33(2):97-104, 2011.

\section{Corresponding author:}

Dr. Ramada Khasawneh, PhD

Department of Basic Medical Sciences

Faculty of Medicine

Yarmouk University

JORDAN

Received: 22-08-2021

Accepted: 25-09-2021

E-mail: ramada@yu.edu.jo 